\title{
Alterations in the Activities of the Nitrogenous Wasteof Clarias Gariepinus after Intramuscular Injection with Aqueous Extracts of Jatropha Tanjorensis Leaves.
}

\author{
O. J. Ogoruvwe* and O. Kori-Siakpere \\ Department of Animal and Environmental Biology, \\ Delta State University, PMB 1 Abraka, Nigeria.
}

\begin{abstract}
Jatropha tanjorensis leaf serve both as food and as medicine. There is need for proper physiological and toxicological tests in order to ensure its safety. The analyses of nitrogenous wastes produced on exposure of Clarias gariepinus to the acute concentration (0.0, 2.0, 4.0, 6.0, 8.0 and 10.0g/L) of aqueous extracts of Jatropha tanjorensis leaf was studied for four days. The result of the nitrogenous wastes parameters showed that serum bilirubin and uric acid, creatinine and urea were significantly higher $(P<0.05)$ in the injected fish, while muscle and kidney bilirubin, and kidney uric acid was significantly lower $(P<0.05)$. The nitrogenous wastes activities of $C$. gariepinus were both dose and tissue dependent. This study highlights the fact that acute concentrations of aqueous extracts of Jatropha tanjorensis have moderate deleterious consequences on the nitrogenous wastes activities of Clarias gariepinus.
\end{abstract}

Keywords: Jatropha tanjorensis, Clarias gariepinus, Bilirubin, Uric Acid, Creatinine and Urea.

\section{Introduction}

Green plants are most significant in their role as producers of food. From them directly or indirectly come animal foods. Protein, carbohydrates and fats as well as accessory nutrients such as vitamins and minerals are all made available to man and other animals through green plants. Jatropha tanjorensis (Ellis and Saroja) belongs to the family 'Euphorbiacea'. Other species are Jatropha curcas, J glandulifera, J gossypifolia, J chevalieri, J elliptica J multifida, J podagrica, and J intergerrima (Carlasabandar, 2010, Oduola et al., 2007). J tanjorensis is a natural hybrid between J. curcas and J. gossypifolia (Prabakaran and Sujatha 1999). J. tanjorensis leaf is commonly consumed as vegetable in many parts of Southern Nigeria. It is commonly called hospital too far, catholic vegetable, lapalapa (Iwalewa et al., 2005).

Another importance of plants is its use in medicine. Medicinal plants are the sources of many important scientific drugs of the modern world. Oduola et al., (2007) showed that J. gossypifolia stem latex acts as a haemostatic agent. J. tanjorensis is popular as a natural remedy against diabetes in Southern Nigeria (Olayiwola et al., 2004).

Although there is growing popularity of herbal medicines as safe, scientist still advocate for proper physiological and toxicological tests in order to ensure safety in the use of traditional medicines (Oyewole et al., 2007, Ozuola et al., 2006). In view of the common use of $J$ tanjorensis both as food and as herbal medicine, there is need for proper physiological and toxicological tests in order to ensure its safety. The toxic effect caused by a drug is similar in man and some other animals, a premise for the use of animal models in toxicological studies (Range et al., 1995) Analysis of biochemical parameters in the serum and tissues are helpful tools in ascertaining the physiological state of the fish.

The objective of present work was to determine the biochemical responses of Clarias gariepinus after intramuscular injection with aqueous extracts of Jatropha tanjorensis leaves. It is with the hope that this research will shed more light on the safety of $J$. tanjorensis in its use both as food and as medicine.

\section{Materials and Methods}

Tank-raised Clarias gariepinus (mean total length $28.39 \pm 0.33 \mathrm{~cm}$, SE; mean weight, $99.34 \pm 2.48 \mathrm{~g}$ $\mathrm{SE}$ ) were obtained locally from a commercial fish farm and transferred to the Animal and Environmental Biology Research Laboratory, Delta State University, Abraka where they were held in large plastic aquaria of $140 \mathrm{~L}$ capacity with clean borehole water. They were then acclimatized for 14 days during which they were fed with commercial fish feed pellets (Coppens) twice daily.

The plant material used in this study was harvested in the month of August 2011 from the vicinity of a home garden in campus II, Delta State University Abraka Nigeria. Dr (Mrs.) E. Edema of the Botany department Delta State University Abraka, Nigeria, identified the plant as Jatropha tanjorensis. Voucher specimen was deposited in the herbarium of Botany department Delta State University Abraka Nigeria. 
The freshly harvested leaves were air dried for 7 days and later dried in an oven at $40^{\circ} \mathrm{C}$ for 12 hours. The dried leaves were grounded into powder with an electric blender, sieved and the fine powder was stored in moisture free, airtight laboratory containers for further use.

A stock solution of $200 \mathrm{~g} / \mathrm{L}$ of the aqueous solution of J. tanjorensis was prepared from the powder with distilled water. After 24 hours, the solution was filtered. The filtrate was then extracted with the aid of a rotary evaporator . Five test concentrations $(2.0 \mathrm{~g} / \mathrm{L} 4.0 \mathrm{~g} / \mathrm{L} 6.0 \mathrm{~g} / \mathrm{L} 8.0 \mathrm{~g} / \mathrm{L} 10.0 \mathrm{~g} / \mathrm{L})$ were prepared by serial dilution for injection of the fish.

After acclimatization, the experimental fish were divided into six (6) groups (10 specimens per aquarium) to assess the acute effect of J. tanjorensis on the biochemical parameters. The upper part of each container was covered with a lid made of fine polyethylene gauze screen of $1 \mathrm{~mm}$ mesh size. Fish specimens were starved for 48 hours before the injection. $2 \mathrm{ml}$ of the extract was injected intramuscularly above the lateral line of the fish. Fish in the control were injected with same dose of distilled water. There was one replicate in each treatment level and the control. Exposure lasted 96 hours.

At the end of the exposure period, five fish were caught individually in a small hand net from the containers. After the preliminary investigation of the length and weight, the fish were then placed belly upwards and blood samples obtained from the caudal circulation with the aid of a heparinised $2 \mathrm{~cm}^{3}$ disposable plastic syringes and a 21 gauge disposable hypodermic needle. The use of plastic syringe is a necessary precaution with fish blood because contact with glass results in decreased coagulation time. The site chosen for puncture (about $3-4 \mathrm{~cm}$ from the genital opening) was wiped dry with tissue paper to avoid contamination with mucus. The needle was inserted perpendicularly to the vertebral column of the fish and gently aspirated during penetration. It was then pushed gently down until blood started to enter as the needle punctured a caudal blood vessel. Blood was taken under gentle aspiration until about $1 \mathrm{~cm}^{3}$ has been obtained, then the needle was withdrawn and the blood gently transferred into lithium heparin anticoagulant tube and allowed to clot at room temperature for 30 40 minutes. Serum was obtained by centrifugation. The serum was transferred into anticoagulant free test-tube and stored in a refrigerator until analyses.

After blood collection, the fishes were sacrificed by a sharp blow on the head, dissected and the desired organs (kidney and muscle) carefully removed. The organs were then pulverized in a laboratory mortar and pestle while extractions were prepared by adding $2 \mathrm{ml}$ of $10 \%$ sucrose solution before been centrifuged and stored in a test-tube in a refrigerator until analyses. The serum and tissue levels of biochemical parameters of glucose, protein, cholesterol and triglycerides were all determined colorimetrically using commercial diagnostic kits (Randox Ltd; UK), with the aid of a spectrophotometer.

Empirical data of the results obtained were subjected to statistical analysis using one-way analysis of variance (ANOVA) to test for level of significance between the various concentrations of Jatropha tanjorensis injected intramuscularly in comparison with the control. Multiple comparisons of the means were analyzed by the Duncan tests. All analyses were performed using the software programme (Graph Pads Prism® Software version 5.0).

\section{Results}

The alterations in the nitrogenous wastes observed in C. gariepinus injected intramuscularly with different concentrations of aqueous/crude extracts of $J$. tanjorensis are presented below.

The mean value of bilirubin of Clarias gariepinus injected intramuscularly with $2 \mathrm{ml}$ of the various concentrations of the crude extract of leaves of J. tanjorensis over a period of ninety-six (96) hours is as shown in figure 1. While serum recorded insignificant decrease $(\mathrm{P}>0.05)$ at the first two concentrations, it recorded significant increase $(\mathrm{P}<0.05)$ at the third, fourth and fifth. Muscle recorded significantly decrease $(\mathrm{P}<0.05)$ only at the fifth concentration. Kidney significantly decreased $(\mathrm{P}<0.05)$ only at the fourth and fifth concentration. Statistically, the activity of bilirubin was most pronounce in the serum, less in the muscle and least in the kidney of the exposed fish after 4 days of exposure period.

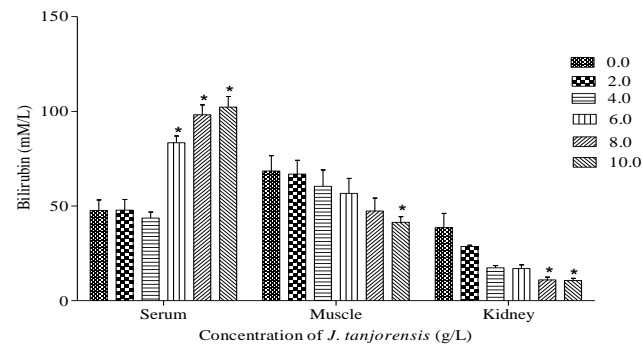

Figure 1: Mean Bilirubin in Clarias gariepinus injected intramuscularly with $2 \mathrm{ml}$ of the various concentrations of the crude extract of leaves of $J$ tanjorensis over a period of 

ninety-six (96) hours. Each column represents the mean value and vertical bars indicate the standard error of the means. Asterisk $(*)$ represents significant difference between the control and experimental group at 0.05 levels.

The mean value of urea of Clarias gariepinus injected intramuscularly with $2 \mathrm{ml}$ of the various concentrations of the crude extract of leaves of J. tanjorensis over a period of ninety-six (96) hours is as shown in figure 2. While serum and muscle recorded significant increase $(\mathrm{P}<0.05)$ only at the last two concentrations, kidney recorded significant increase $(\mathrm{P}<0.05)$ only at the fifth. Statistically, the activity of urea was most pronounce in the muscle, less in the serum and least in the kidney of the exposed fish after 4 days of exposure period.

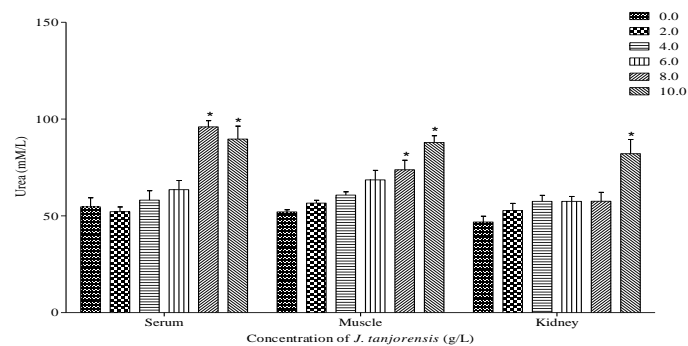

Figure 2: Mean Urea in Clarias gariepinus injected intramuscularly with $2 \mathrm{ml}$ of the various concentrations of the crude extract of leaves of $J$ tanjorensis over a period of ninety-six (96) hours. Symbols as in figure 1.

The mean value of uric acid of Clarias gariepinus injected intramuscularly with $2 \mathrm{ml}$ of the various concentrations of the crude extract of leaves of J. tanjorensis over a period of ninety-six (96) hours is as shown in figure 3. Serum recorded insignificant decreases $(\mathrm{P}>0.05)$ at the first three concentrations and insignificant increase $(\mathrm{P}>0.05)$ at the fourth. However, it recorded significant increase $(\mathrm{P}<0.05)$ at the fifth. Muscle recorded insignificantly decreases $(\mathrm{P}>0.05)$ at all concentrations. Kidney recorded significantly decreases $(\mathrm{P}<0.05)$ at the third and fourth, and at the fifth. Statistically, the activity of uric acid was most pronounce in the kidney, less in the muscle and least in the serum of the exposed fish after 4 days of exposure period.

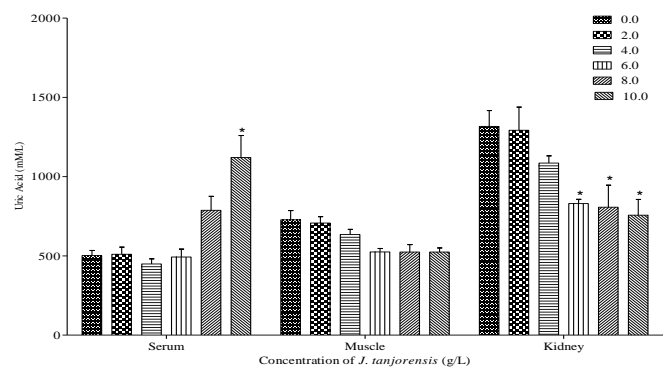

Figure 3: Mean Uric Acid in Clarias gariepinus injected intramuscularly with $2 \mathrm{ml}$ of the various concentrations of the crude extract of leaves of $J$ tanjorensis over a period of ninety-six (96) hours. Symbols as in figure 1.

The mean value of creatinine of Clarias gariepinus injected intramuscularly with $2 \mathrm{ml}$ of the various concentrations of the crude extract of leaves of J. tanjorensis over a period of ninety-six (96) hours is as shown in figure 4. Serum, muscle and kidney recorded insignificant increases $(P>0.05)$ at all concentrations with the exception of muscle that recorded significant increase $(\mathrm{P}<0.05)$ only at the fifth concentration. Statistically, the activity of creatinine was most pronounce in the muscle, less in the kidney and least in the serum of the exposed fish after 4 days of exposure period.

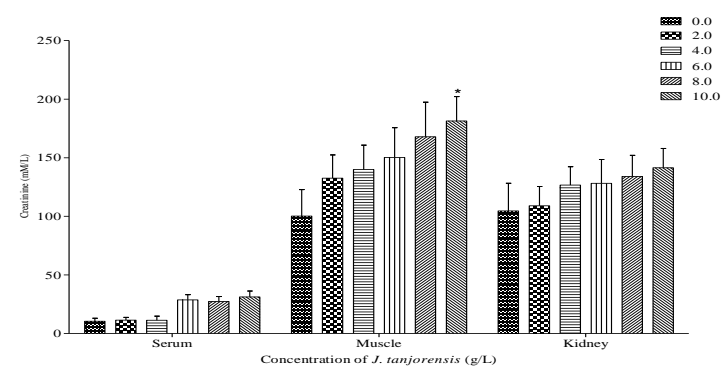

Figure 4: Mean Creatinine in Clarias gariepinus injected intramuscularly with $2 \mathrm{ml}$ of the various concentrations of the crude extract of leaves of $J$ tanjorensis over a period of ninety-six (96) hours. Symbols as in figure 1. 


\section{Discussion}

Urea, creatinine and uric acid levels are indicators of kidney function. Urea is a product of the deamination of glucogenic amino acids in the liver typically in the alanine cycle. Creatinine in serum is a metabolite of muscle creatine. The kidneys usually excrete urea, uric acid and creatinine concentrations. Urea, creatinine and uric acid levels can be used as rough indicators of glomerular filtration rate and kidney functions. Elevated levels of urea, uric acid and creatinine concentrations therefore indicate an impairment in renal function, muscular dystrophia and physical exertion of organisms (Loeb, 1991). The elevations in the concentrations of urea, uric acid and creatinine in the tissue/organ of fish exposed to crude extract of $J$ tanjorensis after 96 hours is therefore indicative of diminished renal function as a result of kidney damage. Okonkwo and Ejike(2011) and Zaki et al (2007) also reported increased level of creatinine, urea and uric acid. On the other hand, decrease in urea and creatinine exposed fish may be an indication of compromised renal function as is observed in mammals (Maita et al., 1984). Barad and Kulkarni (2010), Ogamba, et al (2011) recorded significant decrease in urea, and creatinine.

Low levels of creatinine and uric acid have no significance but increasing their values indicates severe disturbances in renal system (Maxine and Benjamin, 1985). In this study, kidney and muscle uric acid were reduced.

Liver function tests are surrogates for the assessment of toxicity in animals. Elevations in bilirubin concentrations are attributable to liver and/or biliary tract disease (Iyanagi and Accoucheur, 1998). The elevations in serum levels of bilirubin in the fish after 96 hours may be subsequent to the disruption of the hepatic architecture by the $J$ tanjorensis leaf extract that excretion of bilirubin is altered. Muscle and kidney had reduced bilirubin level. Okonkwo and Ejike (2011) recorded both increased and decreased level of bilirubin.

\section{Conclusion}

The result of alterations in nitrogenous waste showed that serum bilirubin and uric acid, creatinine and urea were significantly higher in the injected fish, while muscle and kidney bilirubin, and kidney uric acid was significantly lower. These pathologic changes are sufficient to affect the normal physiology of the fish and will probably result in decreased growth and increased susceptibility to diseases. The results reported in this study have potential implications for fish in nature. Conclusively, this study highlights the fact that acute concentrations of aqueous extracts of Jatropha tanjorensis have moderate deleterious consequences on the nitrogenous wastes activities of Clarias gariepinus.

\section{References}

[1]. Barad, V. S. and Kulkarni, R. S. (2010) Haematological changes induced by short - term exposure to copper in the Indian freshwater fish, Notopterus notopterus (Pallas). The bioscan 5 (2): 313-316.

[2]. Carlasabandar (2010) Secondary metabolite compounds from Jatropha species. www.wordpress.com Accessed 24/09/11

[3]. Iwalewa, E.O., Adewumi, C.O., Omisore, N.O., Adebanji, O.A., Azike, C.K. (2007). Proantioxidant effects and cytoprotective potentials of nine edible vegetables in Southwest. Nigeria. J. Med. Food., 8, 539-544.

[4]. Iyanagi, E.Y. and Accoucheur, S. (1998). Biochemical and molecular disorders of bilirubin metabolism. Biochem. Biophys. Acta 1407: 173-184

[5]. Loeb, S. (1991) Clinical laboratory test: values and implications. Springhouse Corporation, Pennsylvania. pp 124-128.

[6]. Maita, M., Shiomitsu, K. and Ikeda, Y. (1984). Health assessment by the climogram of hemochemical constituents in cultured yellow tail. Bull. Jap. Soc. Scient., 51: 205-211.

[7]. Maxine, M. and Benjamin, B.S. (1985). Outline of veterinary clinical pathology. 3rd edition, Colorado State Univ., Printed in India at Rekha printers PVT. LTD., New Delhi-110020.

[8]. Oduola, T, Adeniyi F. A. A., Ogunyemi E. O., Bello, I. S., Idowu T. O and Subair, H.G (2007). Toxicity Studies on an Unripe Carica papaya Aqueous Extract: Biochemical and Haematological Effects in Wistar Albino Rats. Journal of Medicinal Plants Research 1 (1): 001-004

[9]. Ogamba, E.N., Inyang, I.R. and AlforGod, S.S. (2011) Alterations in the levels of ions in muscle and liver of African catfish, Clarias gariepinus exposed to paraquat dichloride. Research Journal of Biological Sciences 3(6): 547-549

[10]. Okonkwo, F. O. and Ejike, C. E. C. C. (2011) Simulation of heavy metal contamination of fresh water bodies: toxic effects in the catfish and its amelioration with co-contamination with glyphosate. J. Appl. Sci. Environ. Management. 15 (2): 341 - 345

[11]. Olayiwola, G., Iwalewa,E. O., Omobuwajo, O. R., Adeniyi A. A. and Verspihi, E. J. (2004). The antidiabetic potential of Jatropha tanjorensis leaves. Nig. Nat. Prod. Med., 8: 55-58.

[12]. Oyewole, I. O. Magaji, Z. J. and Awoyinka, O. A. (2007) Biochemical and Toxicological Studies of Aqueous Extract of Tithonia diversifolia Leaves in Wistar Albino Rats. Journal of Medicinal Plants Research 1(2): 030-033.

[13]. Ozuola, R.I., Eriyamremu, G.E.. Okene, E.O. and Ochei U. (2006). Hypoglycaemic effects of viscous preparation of Iirvingia gabonensis (Dikanut) seeds in steptozotocin induce wistar rats. J. Herbs Spices Med. Plants, 12: 1-9.

[14]. Prabakaran A. J. \& Sujatha M. (1999) Jatropha tanjorensis Ellis \& Saroja, a natural interspecific hybrid occurring in Tamil Nadu, India. Genetic Resources and Crop Evolution 46: 213-218.

[15]. Range, H. P., Dale, M. and Ritter, J. M. (1995) Pharmacology. $3^{\text {rd }}$ Edn, Church Hill Livingstone, USA, 96p.

[16]. Zaki, M. S., Sharaf, N. E. and Osfor M. H. (2007). Effect of Vanadium toxicity on biochemical, haematological and clinicopathological changes in Clarias lazera present in the Nile River. American-Eurasian J. and Environ. Science 2(6): 741 - 745. 